social functions which form part of the society's annual programme.

Even so, though some degree of disturbance is inevitable, a tour of the works (with the superb view of St Paul's when one reaches the roof via a ladder) fills a mere doctor with wonder that such a complicated project can be managed with such efficiency and precision and that the initial destruction is gradually being replaced by modern buildings, which seem to be climbing up the ancient walls and, no doubt, will soon give the appearance of having been there for centuries.

\section{Archaeological discoveries}

The archaeologists have also been at work. The major focus of their attention has been the masonry of the late thirteenth century Dominican (or Black Friars) monastery. They have identified the south and west walls of the church, several foundation piers for the internal wall of the south aisle, the wall of the guest house, and a cloister wall. Detailed drawings and photography of the medieval walls have revealed the use of a constructional technique known as galeting, in which slivers of flint are inserted between the blocks of ragstone to produce a pleasing decorative effect. This technique was in fashion in the fourteenth century and has not been observed before in London. Other features include a sixteenth century well and a number of seventeenth and eighteenth century cess and rubbish pits which have yielded some interesting pottery.

The progress of the redevelopment has been under the monthly supervision of a committee chaired by Professor Alastair Dudgeon; the society and all its advisers are represented at its meetings and we seem to have been fortunate in that our experts tell us the building has proceeded so far with the minimum of complications and unforeseen difficulties. The programme is virtually on schedule and by the spring of $1985 \mathrm{a}$ Society of Apothecaries will emerge with the façade, ancient hall, and courtyard untouched but with most of the surrounding buildings refurbished to satisfy all its needs for at least the next century. Then it will turn its attention to the southern half of the courtyard and refurbishing the warehouse.

I acknowledge the invaluable help given me by the clerk to the society, Major Charles O'Leary, in checking my facts.

The illustration on the cover is of the Society of Apothecaries.

\title{
Memorials
}

\section{CLAIRE F HILTON}

Leave the familiar square at Barts with its fountain playing, its tall plane trees interspersed with tubs of flowers, its people and cars, and a two minute walk east leads to the green and shady Postman's Park (fig 1). Through the large iron gates is another fountain, flowers, neatly mown lawns, statues, and two fig trees which bear fruit in August and September. The park is a pleasant place to linger on a hot day, but if it is raining there is ample shelter under a long wooden cloister. Come rain or shine, walk towards the cloister, and the blue and white ceramic tiles on the wall ahead will certainly catch your eye. On these tiles are many inscriptions, and when you begin to read you will realise that here is one of the most unusual and touching memorials in London. It commemorates the deeds of heroism performed by 50 or so brave men, women, and children at the turn of this century, people who lost their lives while trying to save others.

Three of the plaques bear testimony to the bravery of medical men. The first, chronologically, tells of:
"Samuel Rabbeth
Medical Officer
of the Royal Free Hospital
who tried to save a child
suffering from diphtheria
at the cost of his own life
October 26 1884.”

Rabbeth was performing a tracheotomy on a 4 year old child Air did not enter the lungs because of secretions blocking the airway so Rabbeth sucked on the tube to clear them. The

St Bartholomew's Hospital, London

CLAIRE F HILTON, MB, BS, house officer

Correspondence to: 26 Abbey Road, St John's Wood, London NW8. 
Rabbeth would most certainly have known of the peril to which he exposed himself, but he persisted with his effort to save the child. Suction apparatus of sufficient force to aspirate thick tracheal secretions was not yet available, though some new designs were in the experimental stages. The latest idea was to use an ear syringe with the hole in the nozzle enlarged. To the nozzle could be attached pieces of rubber tubing of various sizes. The far end of the tube would have multiple perforations so that the trachea could be aspirated before inserting the tracheotomy tube. ${ }^{2}$ Samuel Rabbeth was 26 years old when he died. He was buried in Old Barnes cemetery, near his family home, and the headstone of his grave bears a full description of his life and his sacrifice.

The second medical memorial tells a more cryptic story (fig 2). William Freer Lucas was only 23 when he died. He was

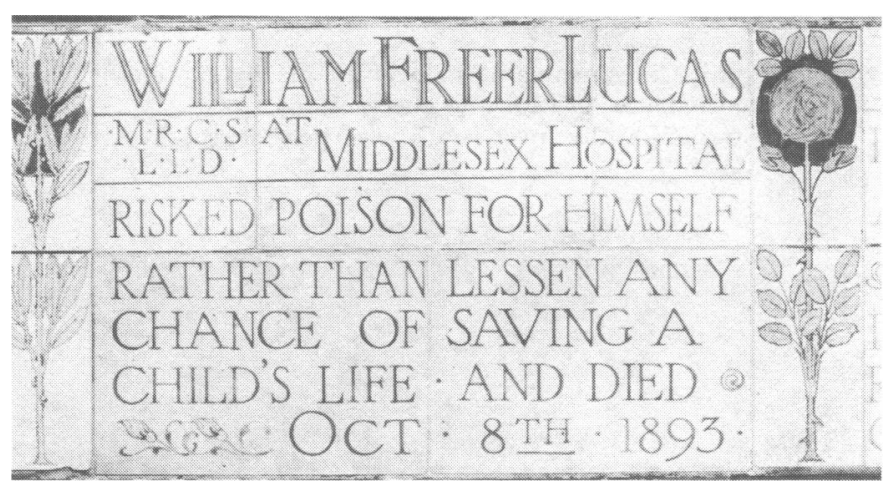

FIG 2-Plaque to William Freer Lucas.

administering a chloroform anaesthetic during a tracheotomy for diphtheria when the child coughed into his face. Ten days later Lucas died of diphtheria. ${ }^{3}$ Had he been infected a year later his chances of survival would have been much greater, because in 1894 horse antitoxin for the treatment of diphtheria was introduced to England and the death rate fell dramatically from $50 \%$ to $16 \%{ }^{4}$ Lucas was a brilliant young man who had won many prizes both at Epsom College and at the Middlesex Hospital. He was the Epsom Scholar in 1888, and after his death that tied scholarship was renamed in his honour. There is a mistake on Lucas's plaque, LLD should read LRCP.

The third gentleman of note is:

"Alex- Stewart Brown
of Brockley.
Fellow of the Royal College of Surgeons
Though suffering from severe spinal injury
the result of a recent accident died
from his brave efforts to rescue a drowning
man and to restore his life
October $91900 . "$

Alexander Stewart Brown was a third generation doctor. His father and grandfather had both been in practice in south London. His FRCS was awarded in Edinburgh, and from 1885 he practised at Holly Lodge, Brockley Road. According to his obituary ${ }^{5}$ the accident referred to in his memorial occurred on
19 September; he was thrown out of his pony and trap and sustained a scalp wound with severe concussion. He decided to take a fortnight's holiday in Paris to help his recovery. On his way, while at Boulogne, Brown saw a man fall into the sea from one of the piers. He dragged the stranger from the water and for two hours, still wearing his sea soaked clothes, struggled to resuscitate the man, with eventual success. The doctor continued his journey to Paris, but returned home after a few days as he felt unwell. Pneumonia set in and he died on Wednesday 17 October 1900 (not 9 October) at Holly Lodge. He was 45 years old.

Look along to the centre of the gallery and you will see a bronze statuette below which is an inscription.

$$
\begin{aligned}
& \text { "In Memoriam } \\
& \text { George Frederick Watts } \\
& \text { who desiring to honour } \\
& \text { heroic self sacrifice } \\
& \text { placed these records here." }
\end{aligned}
$$

Watts was an eminent Victorian artist. He conceived the idea of a national memorial to heroic men and women. A prolonged search was made in the newspaper files of the British Museum for records of such easily forgotten deeds, and the first memorials were dedicated in 1900. After Watts's death in 1904 his wife continued the project. Ninety spaces remain to be filled. The last plaque was erected in $1917 .{ }^{6}$

It is distressing to find so many mistakes when investigating so few plaques in detail, but the memorials are a magnificent testimony to the bravery of individuals who ought to be remembered, and to the ideals of a Victorian gentleman and his lady.

Today Postman's Park is a "city open space" and is maintained by the Corporation of London. Away from the traffic, in a walled garden, a few people hurry through or sit reading newspapers and guidebooks. With the brick church and pretty wooden turret of St Botolph's a few yards away it is difficult to realise that this is the heart of London.

A cursory glance at a fragment of medical history helps to put into perspective the medicine of today, the advances and advantages of modern science. The devotion of doctors of the past, their precise observations of normality and disease, their writings, their lives, and their sacrifices can inspire us today. God forbid that any doctor should die in the course of his duty, but there are still risks with us, the casualty officer who diagnoses lassa fever, the senior house officer in psychiatry who gets into a brawl with a manic patient, the surgeon treating a hepatitis B carrier. There should be no more epidemics of diphtheria and whooping cough, but it was the tragedies of previous years that led people to find vaccines and cures; we must not forget our heritage and our privileges.

\section{References}

1 Anonymous. The lesson of a lost life. $\operatorname{Br} M e d \mathcal{F} 1884$;ii:824-5.

2 Anonymous. Tracheotomy tubes. Br Med F 1884;ii:825.

${ }^{3}$ Anonymous. William Freer Lucas, MRCS Eng LRCP Lond. $\mathrm{Br} \mathrm{Med} \mathcal{f}$ 1893; ii :976.

4 Allbutt TC, ed. A system of medicine by many writers. London: Macmillan, 1897.

${ }^{5}$ Anonymous. Obituary; Alexander Stewart Brown. Kentish Mercury 1900;October 19:6.

${ }^{6}$ Norman BAG. (Introduction). In: Watts' memorial, Postman's park. The story of the tablets. St Botolph's, Aldersgate, 1930. 